\title{
Stakeholder Exposure and Sustainable Supply Chain Management Practices in Safaricom, Kenya
}

\author{
Ogoro Thomas Ombati \\ Management Science, School of Business, University of Nairobi, Nairobi, Kenya \\ Email: thomasombati@uonbi.ac.ke
}

How to cite this paper: Ombati, O.T. (2018) Stakeholder Exposure and Sustainable Supply Chain Management Practices in Safaricom, Kenya. American Journal of Industrial and Business Management, 8, 1139-1156. https://doi.org/10.4236/ajibm.2018.85079

Received: April 10, 2018

Accepted: May 13, 2018

Published: May 16, 2018

Copyright $\odot 2018$ by author and Scientific Research Publishing Inc. This work is licensed under the Creative Commons Attribution International License (CC BY 4.0).

http://creativecommons.org/licenses/by/4.0/

\section{c) (i) Open Access}

\begin{abstract}
Organizations are operating in a competitive business environment where stakeholders are concerned about the type of products and services firms brings to the market. Moreover, the modern customers are knowledgeable and sensitive to the kind of products and service they buy from an organization. The objective of this study was to investigate how stakeholder exposure impacts on the sustainable supply chain management practices in Safaricom, Kenya. The study adopts a case study design, focused on Safaricom, one of Africa's most innovative cellular firms. The study gathered data from Safaricom management, community, Communication Authority of Kenya (CA), corporate customers, and the suppliers. The study adopted semi structured interview protocol to collect data. This study will be analyzed by use of content analysis. Understanding the impact of stakeholder exposure on SSCM practices was critical in ensuring that stakeholder requirements are met.
\end{abstract}

\section{Keywords}

Stakeholders, Stakeholder Exposure, Sustainable Supply Chain Management Practices, Sustainability, Cellular Industry, Safaricom, Kenya

\section{Introduction}

Contemporary organizations have found it necessary to re-examine the management of the activities that take place throughout their supply chains. This implies that supply chain management (SCM) plays a central role in ensuring that the organization is efficient and effective in its operations [1]. However, recent developments such as the need to take into account social and environmental issues have forced organizations to consider sustainability of their supply 
chains. A supply chain needs to take into consideration the needs of its stakeholders in order to be meaningful.

Regardless of whether organizations are motivated by profit or not, they are always concerned with how they relate to stakeholders within a given environment. Firms are constantly apprehensive about what goods or services they deliver to their customers. This is because, in the absence of customers, there will be no business. They need to think and act strategically; translating organizational insights into effective strategies that can help respond to dynamic environment and lay a strong foundation for the implementation of strategies [2]. Grant's observation implies that organizations operate within a wider environment that is composed of a number of factors: political, economic, socio-cultural, technological, ecological, and legal. Consequently, any change in any one of these variables is expected to have far-reaching implications in the way organizations operate. This forces organizations to adopt SSCM practices in addressing any change that may occur in any of the variables so as to optimize on the mentioned variables.

Organizations have goals and aspirations that compete with each other. The goals of businesses are achieved through the application of change management approaches including SSCM [3]. [4] asserts that for businesses to thrive, economic development should be balanced with the societal and environmental practices. This is because of "green consumerism" as echoed by [5] that results in stakeholders advocating for products and services that are environmentally friendly.

Safaricom has been experiencing a sustained growth and development in the last seven years. Its revenues have been increasing steadily. However, that firm has a host of questions regarding its sustainability issues such as network stability, dynamic regulatory environment, energy security, innovation, supplier ethics and performance, ethics and values, employee environment and environmental performance. [6] [7] revealed that there is need to consider stakeholder exposure (control and accountability) to particular social and environmental issues across a firm's supply chain. [8]'s study concluded that a firm is required to adopt an integrated approach in its supply chain in order to address pertinent economic, environmental and social issues. These studies confirmed a need for a research on stakeholder exposure and SSCM practices in the cellular industry. At global and national level, there is no evidence of studies on stakeholder exposure and SSCM practices in the telecoms industry. It is based on this gap that the researcher found the need to bridge the gap in this area. The study sought to achieve two objectives namely: to determine the extent to which Safaricom incorporates stakeholder exposure into their Sustainable Supply Chain Management practices (SSCM) practices and how the stakeholders hold Safaricom accountable and exercise control over Safaricom's Sustainable Supply Chain Management practices and to establish the role of stakeholder exposure in Safaricom SSCM practices. 


\section{Literature Review}

The stakeholder exposure of the firm is determined by a combination of control and accountability to stakeholders [7]. Control is the ability for a firm to influence decisions that have an effect on the stakeholders. The capacity of a focal company to exert pressure on supply chain partners for instance, customers or suppliers is fundamental to exercise control over the stakeholder [7] [9]. Control does not necessarily involve taking action. It includes declining to take action, ignoring the concerns of the stakeholders, neglecting to take action, failing to take due diligence or choosing not to act [7]. However, every choice taken has a consequence. It is only the stakeholders who have a direct economic interest who can claim control of a certain firm.

Control from the firm's perspective is its ability to make decisions without being influenced by other parties. The level of influence by a firm on other supply chain actors is fundamental in determining control [9]. There are two types of influences; economic and non-economic. The economic influence determines the level of control a firm has on its stakeholders, for instance the customers and the suppliers [7]. Moreover, if buying organizations are few in the market due to consolidation, they tend to have influence over their suppliers [9] [10] [11]. Furthermore, regular meetings held by between the buyers and suppliers helps improve the quality of supplies and a focal firm in collaboration with a particular supplier adopting industry norms to control the behavior of other supply chain partners. Non-economic influences determine the level of control over a firm. Examples of non-economic influence include: the environmental regulation of cell phone emissions, social media usage by customers and tower installations.

Accountability has been defined by [7] as the degree to which an organization is held responsible by stakeholders for certain decisions or actions; for instance, product or service design, sourcing, procurement, production or distribution to the stakeholder. According to [12], accountability emanates from stakeholder salience. The stakeholders have a moral obligation to seek an explanation from the firm concerned for any decision or action taken for the sake of their interests. The external stakeholders challenge firms to be more visible and transparent in their operations. This make firms to sustain legitimacy, build reputation and become more competitive [13]. Therefore, the buying organizations need to be worried on the environmental production/service procedures for instance, ISO 14001 [14]. Moreover, the public involvement through scrutiny on a firm's operations forces the management to be transparent regarding their environmental, social and economic performance [15]. The greater the extent of stakeholder attributes namely, power, legitimacy and urgency, the greater the level stakeholder salience and its propensity to hold a focal firm accountable for its decisions [7].

Stakeholder exposure entails two variables which include: accountability and control. Stakeholders are classified according to their ability to control a firm's 
decisions or actions and their propensity to hold the firm accountable for their outcomes. The stakeholders are categorized by the use of a quadrant. This is shown in Figure 1.

In the first quadrant both accountability and control of the stakeholders is low. This implies that the stakeholder's salience, that is the importance of a given stakeholder to a firm and its interest for the economic welfare is low. Such stakeholders have little or no influence on the decisions and actions that a firm takes. These stakeholders have little or no economic interest in the firm. For instance, in a case of a small-scale entrepreneur involved in trading energy saving lights in the village, there is a limited market for the products whose stakeholders have limited accountability and control. Issues in this quadrant are known as trivial.

In the second quadrant, the situation has a low level of accountability while the extent of control of the stakeholders is high. This means that the importance of a particular stakeholder to the firm is low while the level of control of the particular stakeholder is high. For instance, the vehicle drivers in Kenya are prohibited by the law from using cellular phones while driving. Therefore, in case an errand driver causes an accident due to making or receiving a phone call while driving, despite the stringent control measures, Safaricom as the service provider cannot be held reliable (accountable) for the misfortune caused. According to [7] cellular phone manufacturers can be given pressure to install technology devices in the phones that disables the use of the phone while driving. Issues in this quadrant are known as evolving.

In the third quadrant, the stakeholders to a firm have low level of control while its accountability is high. The stakeholder's importance in terms of holding a firm responsible for its decisions and actions is high but low level of control. For instance, in the cellular industry, a group of activists who marches to Safaricom headquarters with placards that say "no call rate reduction, no business for you". This noise from the activists may be extremely irritating to Safaricom management but may be ignored. The issues under this quadrant are known as demanding.

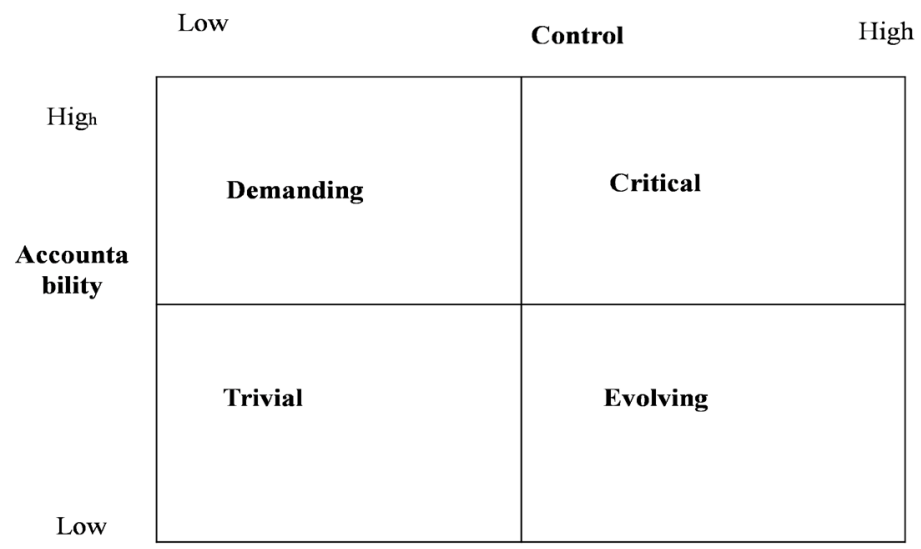

Figure 1. Stakeholder exposure. Source: Adapted from Parmigiani et al., (2011). 
The fourth quadrant represents stakeholders whose accountability and control are both high. The issues under this quadrant require an immediate action from the firm's management. An example here is when a cellular corporation underpays its worker, leading to high employee turnover. The cellular firm in this case is held responsible for this trend while it can also control the massive exit of its staff by acting on their claim. The issues under this quadrant are considered critical.

\section{Conceptual Framework}

Stakeholder exposure plays a very significant role in ensuring that an organization implements sustainable supply chain management practices in its supply chain. Stakeholder exposure comprises of both accountability and control. Accountability ensures that cellular companies are answerable to all the activities they carry out in the supply chains whereas control refers to ability of the firm or stakeholders to regulate the activities of a cellular company. Control and accountability individually and collectively have influence on stakeholder exposure. The greater the economic and non-economic influence of stakeholders, the greater their control over the firm and when the stakeholders hold a firm accountable on its supply chain decision, the firm is bound to observe its supply chain activities. A firm's SSCM practices depend on the level of stakeholder exposure. Figure 2 presents a conceptual framework that guides this particular study.

Control by the firm and accountability to stakeholder determines the firm's stakeholder exposure. The level of exposure to any particular stakeholder is thus dependent on the level of influence over the firm and on the stakeholder's salience [7]. If the level of both control and accountability are low, the issues are regarded as inconsequential. If control is high while the accountability is low, the issues here are termed as emergent. Demanding issues are determined when accountability is high while control is low. Foundational issues are as a result of greater control and accountability [7]. This lead to the following propositions:

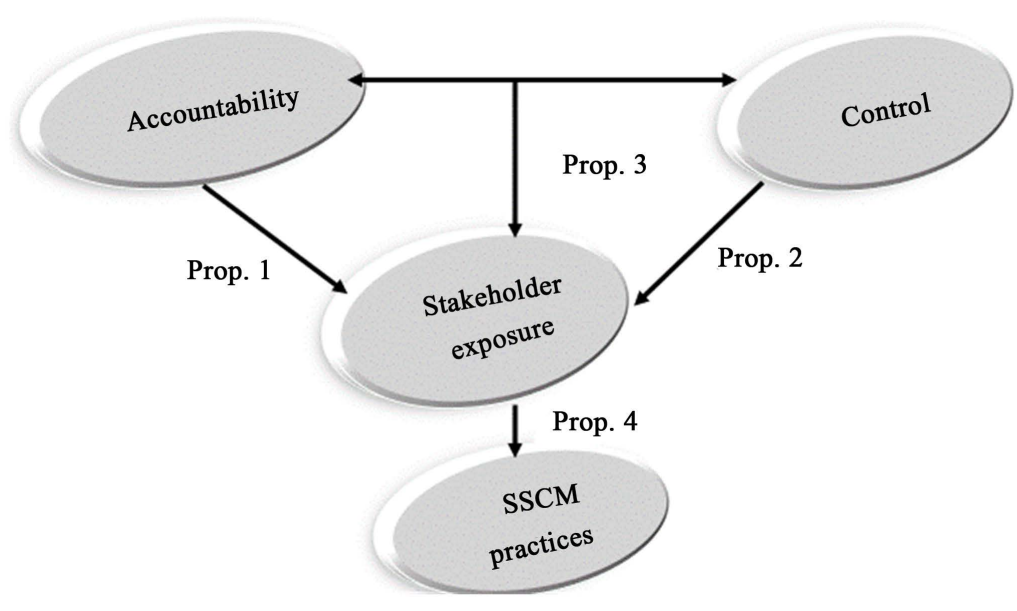

Figure 2. Conceptual framework. Source: Developed from Parmigiani et al. (2011). 
Proposition 1: The greater the propensity of the stakeholders to hold the focal company accountable for its decisions, the greater the stakeholder exposure.

Proposition 2: The greater the control of the focal company to make decisions, the greater the stakeholder exposure.

Proposition 3: Stakeholder exposure is greatest when both control and accountability are mutually reinforcing.

The level of control and accountability determines the stakeholder exposure and this has an influence on the SSCM practices adopted by a firm. When both control and accountability are low, the social and environmental issues along the supply chain are minimal [7]. This implies that the level of stakeholder exposure has an influence on the SSCM practices adopted and this determines the level of attention accorded to the social and environmental issues. For example, when control is high and accountability is low, product safety is of great concern. According to [15] stakeholders exert moral suasion over SSCM of a firm. This lead to Proposition 4: The greater the degree of stakeholder exposure the greater the adoption of sustainable Supply Chain Management Practices.

\section{Research Methodology}

This chapter focuses on the methodological aspects of the study. It outlines the direction taken right from research conceptualization through to the analysis of the collected data. The areas covered under this section include: research design, selection of the firm and selected stakeholders, target respondents, data collection, analysis, reliability and validity and ethical issues. Understanding these methodological aspects lead to the next chapter.

The research adopted a single case study embedded with four units of analysis namely community, regulator (CA), corporate customers and suppliers. [16] argues that an embedded case study involves multiple units of analysis within a case and that its adoption is based on the context and the objectives of the study. An embedded case study approach was considered appropriate because of the nature of the study that required different views on stakeholder exposure and SSCM practices in Safaricom. This research design was appropriate since it sought to bring out in-depth understanding of the concepts under study from the perspective of the four stakeholders in the Kenyan cellular industry. This design gives the respondents an opportunity to share their views without restrictions [16].

However, case studies are considered to lack rigor [17] but if the procedure of conducting the case study is carried out in a structured manner, case study design yields better results through in-depth understanding of a complex phenomenon. In achieving rigor in case study, quality criteria such as selection of the case, data gathering, validity and reliability need to be considered [18]. In order to ensure sturdiness in the design of the case study, the researcher observed essentials such as developing and using a conceptual framework from which propositions were developed, generated the "how" and "why" research ques- 
tions, linked the data to the propositions and identified the criteria for interpreting the research findings [16] [19].

\subsection{Selection of the Firm and Stakeholders}

According to [16] selecting the firm is a very important research component. A firm has to be selected for theoretical reasons, specifically appropriate for informative and extending the evolving theory [20]. Safaricom; community, regulator (CA), corporate customers and suppliers were selected for this study. Moreover, four types of stakeholders were selected for this study because they were considered sufficient to provide the required data. Due to scarcity of resources it is difficult to satisfy all the stakeholders' requirement, hence need to compromise [21]. This fact is echoed by [22] who asserts that an optimal number of cases in a study are achieved when any extra addition of a case to the selected units of analysis does not add value to the study.

Safaricom was selected for this study because it is the first and only Kenyan cellular company to produce a sustainability report. In addition, it is the dominant player in cellular sector in Kenya; it is innovative and has grown its market share rapidly in the past decade. The study targeted a number of respondents at management level from various departments in Safaricom and selected four stakeholders. The protocol targeted multiple respondents from multiple functional areas. This included senior managers from Supply Chain, Finance, Corporate Affairs, Health and Safety, Innovation, Strategy, Sales and Marketing, Research and Development and the person responsible for Sustainability. The rationale for the choice of the senior managers is that they are responsible for monitoring and controlling the company's sustainability issues in the firm. Moreover, interviewing multiple respondents allowed the researcher to examine various areas of the company's supply chain and triangulate the data. This approach to data collection is based on an approach that was designed and successfully applied by [23].

This study solicited data from twenty-nine participants. This number was considered appropriate because the data collected reached a point of saturation. [22] alludes that at saturation point, any additional data to a study adds little or no value. The interview process captured information using a voice recorder and note taking. However, some respondents were not comfortable with the use of a digital device and this compelled the researcher to take notes while interviewing. The approximate time taken to interview each informant was 75 minutes. The study also made use of published reports. For instance, Safaricom's annual reports, website, trade journals and Communication Authority of Kenya (CA).

\subsection{Data Analysis}

Data was analyzed by use of content analysis. This involves movement back and forth between conceptualization, data collection, analysis and interpretation [24]. Common themes underlying stakeholder exposure namely; control and accountability and SSCM practices were identified. Content analysis used a sys- 
tematic approach to summarize the data packets into themes. The themes were classified into various patterns which were then followed by building of valid arguments from the analysis. This was done by comparing the themes with the proposed conceptual framework.

This study adopted a "within case analysis approach" where Safaricom management, community, regulator (CA), customers and suppliers were analyzed separately and then later conducted cross-case analysis to identify similarities and differences [16] [25]. The data collected was initially arranged systematically to allow the researcher to gain insight and better familiarize himself with it before transcribing it. This was followed by a write-up of the stories presented from the four cases and the management. The main focus for this was to summarize the large amount of data to a manageable size and build up case-specific insights before identifying and linking the patterns across cases. During cross case analysis process, identification of within-group similarities and between-group differences was done after the selection of categories of research themes [19]. Interpretation of the research findings was finally followed by study conclusions and subsequently testing for validity of the results by counter checking extant literature and subjecting the study report to key informants within the cellular industry who comprise a few selected scholars in the subject area.

\subsection{Reliability and Validity}

Reliability was achieved by developing and refining the interview protocol and then submitted to my supervisor for criticism and review. This achieved conformability design test. I also discussed with one of the key informants in Safaricom the content of the interview guide to ensure that the instrument is dependable and clear. The researcher also recorded the proceedings during the data collection process by using a voice recorder and records the data mechanically to develop the case [26].

Construct validity is concerned with the researcher's ability to single out meaningful and reasonable conclusions on the sample or population under study. It is the extent to which the empirical indicators match the concepts under study [16]. The study adopted various techniques in testing and ensuring that construct validity was achieved. The conceptual definition provided by [12] was adopted. The study also used multiple sources of data for instance interviews with Safaricom managers and stakeholders, sustainability reports, unpublished reports, journals and newspaper articles. Internal validity ensured credibility of the study. This ensured that there is internal coherence of the study and that the concepts are systematically related. The study achieved this through researcher self-monitoring and triangulation. The last form of validity tested was external validity. Comparison between the information gathered and the extant literature was also made [26]. This was achieved by use of theoretical terms and relationships as used by the works of various authors especially [12] [27]. 


\section{Research Findings}

This section covered analysis of data and the results arising from the interview conducted. The main objective of this study was to investigate how stakeholder exposure impacts on the sustainable supply chain management practices in Safaricom, Kenya.

The customers have both high control and accountability. They are therefore considered to have the highest level of exposure. It was established that the high level of control emanates from both economic and non-economic influence. This set of stakeholders is considered critical by Safaricom. Customers hold Safaricom accountable on its decisions through consultative meetings, communication through emails and other channels as dictated by the Kenyan law.

Safaricom has high control over suppliers due to both economic and noneconomic interest they possess. Suppliers need payment for their supplies and hence call for high level of control. On the other hand, the firm has varying level of accountability to its suppliers. For instance, suppliers who provide monopolistic services such as Kenya Power require more accountability from Safaricom and vice versa.

The study findings indicated that the community is in the first quadrant where both control and accountability are low. Safaricom has a low level of control over the community's activities and therefore it cannot be held accountable for a certain situation over which it has little or no control. Issues under this quadrant are regarded as trivial. Safaricom has a low level of control and high-level accountability to its regulators. This is an outcome of the need for the regulators to influence the distribution of both frequency numbers and spectrum frequency. The regulators also charge license fee for this resource. Issues in this quadrant are regarded as demanding and thus need urgent attention. This discussion of summary is shown in Figure 3.

Stakeholders have various expectations and hence need to hold Safaricom accountable and exercise control over Safaricom's SSCM practices. For example, one of the customers interviewed, said "We prefer that goods and services be delivered as soon as possible not considering the cost implications of the same, vendors at times give lead-times that they might not be able to meet deadlines hence causing delays and of course this has a cost implication on projects". This is however addressed through consultative meetings to ensure that all understand the importance of efficiency and timely deliveries. Expectations of

\begin{tabular}{|l|l|}
\hline Regulator issues (ii) & Customers issues (iii) \\
-Demanding & -Critical \\
\hline $\begin{array}{l}\text { Community issues (i) } \\
\text {-Trivial }\end{array}$ & Suppliers issues (iv) \\
& -Evolving \\
\hline
\end{tabular}

Figure 3. Stakeholder exposure in Safaricom. Source: Author, 2018. 
various stakeholders and how they hold Safaricom accountable over Safaricom's SSCM practices are shown in Table 1.

The researcher revealed that stakeholder exposure is a result of the stakeholder's propensity to hold a Focal Organization (FO) accountable on its supply chain decisions and the level of control a firm has over the stakeholders. The regulator (CA), for example, was found to possess a high level of exposure and based on the powers bestowed upon it by law; it is able to be accorded maximum attention by Safaricom on matters related to the activities affecting customers and the community. Accountability of the FO to the stakeholders through regular meetings ensures adherence of Safaricom to deliver on its promises to the stakeholders while its capacity to have control over its stakeholders was found to make it easy to discipline a misbehaving stakeholder by either withdrawing financial benefits or terminating a contract.

The respondents were also required to state Safaricom's level of accountability and control in regard to the firm's economic, social and environmental supply chain activities. It was clear from the study findings that the community has both low control and accountability over the firm's decisions. Safaricom has low level of control over the community's activities and therefore it cannot be held accountable for certain situations over which it has little or no control.

The community makes Safaricom accountable by involving them through continuous consultations, sharing development and benefits to the society. The study also found out that Safaricom also involves the community in energy

Table 1. Stakeholder exposure and SSCM practices.

\begin{tabular}{|c|c|}
\hline Stakeholder & Accountability over Safaricom's SSCM practices \\
\hline $\begin{array}{l}\text { Shareholders } \\
\text { (Government of } \\
\text { Kenya, Vodafone } \\
\text { PLC. and public) }\end{array}$ & $\begin{array}{l}\text { Engage with the government through the relevant ministries on various } \\
\text { environmental matters for instance e-waste regulations. Vodafone } \\
\text { Plc shares information regarding new technologies and best practices } \\
\text { in supply chain management; for example, energy and carbon footprint. } \\
\text { This is done through monthly meetings and teleconferences held as } \\
\text { planned from time to time }\end{array}$ \\
\hline Regulators & $\begin{array}{l}\text { Engagement on respective regulator's Key Performance Indicators } \\
\text { (KPIs). For instance, Safaricom engages with CA on its targets. } \\
\text { This engagement is done through regular meetings, submissions } \\
\text { and formal correspondence }\end{array}$ \\
\hline Employees & Through labour unions, consultative meetings or industrial disputes \\
\hline $\begin{array}{l}\text { Suppliers/Innovation } \\
\text { partners }\end{array}$ & $\begin{array}{l}\text { The key issue is value proposition. Safaricom involves its partners on } \\
\text { issues regarding product and service development. Some of the } \\
\text { partners include; mobile manufacturers for instance, Samsung and } \\
\text { Nokia, developers and technology innovators. This is achieved through } \\
\text { daily Safaricom innovation email, sharing ideas with recipients and } \\
\text { encourages them to express their feedback and interest }\end{array}$ \\
\hline Local community & $\begin{array}{l}\text { The community is involved in the process of participation during } \\
\text { Environmental Impact Assessments (EIAs) of proposed projects. } \\
\text { This is done through regular meetings as required }\end{array}$ \\
\hline Customers & Regular meetings between Safaricom and customer representatives \\
\hline
\end{tabular}

Source: Author, 2018. 
management and conservation. The firm has demonstrated use of clean energy like solar power in their shelter sites and helped to distribute the same to the communities where it is operating.

Safaricom has a high level of control in communities especially where it sets up their infrastructure and operation; they are obliged to continuously engage with the community in matters affecting them. However, it was established that the community has no control in places where Safaricom has not set up any infrastructure. The study findings indicated that the local communities are consulted by Safaricom when proposed designs are being investigated, and environmental impacts are also assessed during these investigations. This is carried out as part of the Environmental Impact Assessment (EIA) process and while addressing mitigation measures. Moreover, the study found that the firm puts a lot of emphasis on the improvement of the environment around their sites, set up schools, install motion lights to improve security and offer free phone-charging booths.

The community calls upon Safaricom to publish a Safety and Environment policy, accidents and hazard reports and impress upon the firm to conduct public education and awareness campaigns for the community.

The study points out that it necessary for Safaricom to cultivate positive relationships by maintaining the community in which it operates and make sure they give back to society. In addition, to ensure accountability, Safaricom keeps an open door for interactive dialogue, be it questioning, feedback or discussion. They are open to the community's opinions, participation and finally make sure the opinions given by the community are meaningful. The study revealed that Safaricom has a low-level accountability over the firm's SSCM practices.

The researcher sought to establish the mechanisms the regulators have put in place to ensure accountability from Safaricom's activities. It was revealed that the regulators command a high-level accountability regarding SSCM practices from Safaricom. It was evident from the research findings that regulators have a number of mechanisms to ensure that Safaricom is accountable to its activities. One the mechanisms as established from the study is that of periodic reporting of the activities the company is involved in. The study established that regulators require Safaricom and other firms operating in the industry to submit regular reports of all the activities they are involved in. The researcher observed that submission of these reports is not optional but an issue the company must comply with.

The other mechanism that regulators have put in place is the requirement that Safaricom and other companies in the telecommunication industry must prepare sustainability reports on an annual basis. The findings revealed that the annual sustainability reports prepared by the company outline the various activities the company is involved in and the efforts the company is making to ensure that all its activities are sustainable in the long run. The study observed that a copy of these report must be delivered to the relevant regulator in order to provide them with information concerning the activities of the company. 
The regulators do not struggle to have Safaricom as a company to reveal the important information to them. The reason as revealed from the research findings is that regulators do not propagate imaginary concerns but rather legitimate concerns that are based on an existing legislation. The study established that regulators demand that the necessary exposure of information be done as and when expected since this is the requirement by law. "The law gives us power to demand for exposure of information on the various activities that are being carried out by the company and that this must be done within the law and within the expected duration. You need to understand that we have made known to Safaricom their expectations on exposure concerning the activities they are involved in". This is very important in ensuring that the company is aware beforehand of what is expected of it by the regulators even before engaging in any activity.

Sustainable supply chain management concerns regulators advocate for, revolve around better environmental practices such proper management of frequency spectrum in order to ensure that they are less harmful to the users and the environment, on the financial aspect the regulators require that there should be reasonable tariffs that will not lead to price wars in the industry and that the firm has to use products that will generally not be harmful to the environment and the customers. It was revealed that these sustainable supply chain practices advocated by the regulators are clearly spelt out in the law they are supposed to enforce. Their advocacy in these SSCM practices therefore mainly features what the law stipulates. It was also established from the study that quality of services and products must not be compromised by the firm in the name of SSCM practices.

In regard to how customers hold Safaricom accountable for the supply chain decisions, corporate customers have various ways of ensuring that Safaricom is accountable to its decisions. The corporate customers serve the company's expansive subscriber network and this is very important for Safaricom. The company understands that failure to be accountable to its corporate customers may negatively impact on the subscribers. The corporate customers make the company understand their pivotal role in the provision of telecommunication services to its customers. Corporate customers therefore rely on this understanding to push their agenda of accountability on Safaricom's SSCM decisions. It was further observed that corporate customers also use their position especially the leading twenty to fifty dealers or distributors to put pressure on the company to be accountable for its activities. Being the leading corporate customers, they hold a significant position that touches on the revenue earning capacity of the company. This position provides them with ground to agitate for accountability on the decisions made by Safaricom.

Safaricom ensures that all the customers are provided with the relevant information that will provide them with the necessary exposure on the SSCM activities being undertaken by the company. The company also ensures that all accountability concerns that are voiced by the customers are adequately handled 
to avoid standoff between the company and them. The company has also provided guidelines on the timeframes and quality standards that customers should expect. This serves as accountability guidance to the stakeholders. It was further noted from the study findings that Safaricom considers three main factors in managing its exposure. The first factor relates to the power that a stakeholder has in influencing the company decisions.

The study was meant to establish from the corporate customers their level of exposure and how it contributed to sustainable supply chain management activities that are adopted by Safaricom. One of the dealers posited, "We used to have monthly meetings with the company until the year 2012. However, over time, the frequency of the meetings has been deteriorating since the company has resorted to segmentation of its customers. For instance, the company currently segments its dealers based on their performance and regions. The top twenty to fifty dealers are given more attention because they contribute a lot to the activities of the company. The frequency of the meetings has also reduced due to the use of area managers by the company to communicate to their corporate customers in various regions". This level of communication has been very instrumental in providing the corporate customers with relevant information concerning the sustainable supply chain management activities that are adopted by the company. It has also assisted the corporate customers to align their concerns with SSCM activities that the company is engaged in.

It was also clear from the research findings that the corporate customers have a number of sustainable supply chain concerns that they advocate for. One of these concerns relates to trade in mobile telecommunication devices and equipment that have minimal harmful radiations to the users and to the environment. The corporate customers advocate for the company to source for more user friendly and environmental friendly gadgets and equipment that will ensure safety to users and environment. The corporate customers also advocate for more lean and agile supply chain systems that will reduce the cost of service delivery to the customers as this will reduce the prices of products and services. The other SSCM management practice that corporate customers advocate for is the introduction of gadgets that are capable of utilizing more of renewable than non-renewable energy.

It was established that the other SSCM concern corporate customers advocate for is the use of products and services that are re-usable and re-cyclable. This implies that corporate customers are more interested in products that can minimize the damage caused to the environment. They also advocate for products and services that are safe to both the employees and the customers and equally meet socially responsible standards. The corporate customers also advocate for electronic top ups of credit. This is aimed at reduction of credit vouchers that are normally made from paper. This ensures that the company is adopting measures that can assist in the reduction of deforestation and other practices that can cause harm to the environment. They also insist on digital communication of any information between the company and corporate customers. The company 
has a large number of dealers and distributors and effecting digital communication is one way of reducing printed communication materials that utilize a lot of paper.

The study further sought to establish the achievements that have been made by Safaricom in terms of Sustainable supply chain management practices. The findings revealed that the firm has made a number of achievements in ensuring that they move towards a sustainable supply chain. It was clear from the results that although the suppliers are largely dictated on what to do and provide, the firm takes into consideration the sustainability of all the resources the suppliers are supposed to provide. It was evident from the study findings that the suppliers are required to provide resources that meet the three dimensions of financial, social and environmental. The findings indicate that this is considered one of the most important achievements made by the company in moving towards sustainable supply chain management.

Safaricom has also made several strides in ensuring reduction in use of paper in most of their operations. The study findings confirmed that the introduction of electronic top up is one of the ways through which the company has been able to reduce use of paperwork. This is one of the achievements that depict the sustainable supply chain management practices the company is implementing.

\subsection{Discussion of the Findings}

Safaricom has a high level of control on its customers and suppliers due to their economic interest. It was established that customers are interested in innovative and quality of products and services while the suppliers are more interested in the payments for their supplies. This finding is consistent with [7]'s work that states that control relates with stakeholders who have economic interests in the supply chain outcomes, primarily customers and suppliers. Moreover, if the number of buyers is fewer than the suppliers in the market, the buyers will have the market power which subsequently translates to greater influence over the suppliers [9] [10] [11]. However, the study findings indicated that Safaricom does not have control over the activities of the community where they are operating.

Focal firms hold regular meetings with suppliers to improve the quality of supplies. This practice ensures collaboration with suppliers and this has influence on the behavior of other supply chain partners [7]. These authors also conclude that industry norms that originate jointly from buyers and a particular supplier influence the behaviors of other suppliers in the market. The study also noted that Safaricom holds meetings with the corporate customers, regulators and community leaders to evaluate the level of satisfaction from both the stakeholders and Safaricom.

While suppliers and subcontractors to Safaricom are required to sign a code of conduct regarding to the adherence and observation of high standards, holding of regular symposiums with the suppliers and competitors on environmental matters is very important, [14] argued that the buying organizations need to be 
apprehensive on the environmental production/service procedures for instance, ISO 14001. The study also revealed that customers need to see that products and services are tagged to better prices, open engagement of Safaricom with competitors in a fair and transparent manner without taking advantage of the perceived market dominance and ensuring that Safaricom doesn't act in any monopolistic tendencies which can hurt the customers, community, employees, suppliers, the government and generally the cellular industry.

Open discussions with stakeholders on the sustainability agenda, seeking feedback and suggestions on how to improve on sustainability, use of branding and images to publicize the sustainability programmes and involvement of sustainability partners in Safaricom functions were found to increase accountability of Safaricom's sustainable supply chain practices. This study finding agrees with the practice of public scrutiny on a firm's operations that force the management to be transparent regarding their environmental, social and economic performance [15]. According to [28], transparency across the industry of respective contract factories promotes greater collaboration, sharing of monitoring information and reinforcement of remediation expectations across the industry. The communities and other external stakeholders challenge firms to be more visible and transparent in their operations. This make firms to sustain legitimacy, build reputation and become more competitive [13].

\subsection{Conclusion}

Stakeholder exposure is managed in order to actively involve the stakeholders in achieving the firm's objectives. Understanding the impact of stakeholder exposure on SSCM practices was critical in ensuring that stakeholder requirements are met. It strengthens the relationship between the stakeholders and managers of a firm, clearly identifies KPIs and what SC activities are needed in Safaricom.

Stakeholder exposure is a result of the stakeholder's propensity to hold a Focal Organization accountable on its supply chain decisions and the level control a firm has over the stakeholders. The regulator (CA), for example, was found to possess a high level of exposure and based on the powers bestowed upon it by law; it is able to be accorded maximum attention by Safaricom on matters related to the activities affecting customers and the community.

Accountability of the FO to the stakeholders through regular meetings ensures adherence of Safaricom to deliver on its promises to the stakeholders while its capacity to have control over its stakeholders was found to make it easy to discipline a misbehaving stakeholder by either withdrawing financial benefits or terminating a contract.

\subsection{Study Implications}

This study will contribute theoretically to the existing literature on stakeholder and exposure, SSCM practices. Moreover, it will enable professionals and academicians to gain a clear understanding of major practical challenges in the field. This study will also facilitate theory building which will subsequently be 
used as reference for future studies. It will also identify the applicability of specific features of the existing literature in the context of developing countries, hence stimulating further research.

The link between stakeholder exposure and SSCM practices lead to various managerial implications. The study helps managers to comprehend how to account for their decisions to the stakeholders. The study will help the management to understand the impact of accountability and control on stakeholder exposure. This will ensure a systematic manipulation of the mentioned variables thus leading to the success of a firm.

The research enables managers in cellular industry to understand the value of stakeholder exposure and its impact on SSCM practices. This aids management in cellular firms to align stakeholder exposure with SSCM practices hence improve reputation and sustained growth of the firm. Moreover, the study will help managers to understand the role of supplier collaboration in the cellular firms. It points out the value of collaborating with suppliers on SSCM practices. The study encourages Safaricom management to embrace the art of partnering with it stakeholders on sustainability issues.

\subsection{Recommendations for Future Research}

The trends and gaps acknowledged in this research compelled the advancement of a convincing plan to guide future research on stakeholder exposure and SSCM. This study focused on stakeholder exposure and SSCM practices in the cellular firm. The outcomes of this study provide useful insights for future study. The researcher suggests the following studies to be conducted:

A study on aligning stakeholder exposure with SSCM practices and TBL performance outcomes in the cellular industry in Kenya needs to be done. This study should also expand the list of the stakeholders. This will help the researcher to mitigate the limitations mentioned in this study.

There is also need for a study on stakeholder salience, influence, exposure, SSCM practices and TBL measures in the food sector in Kenya. A study on SSCM practices and TBL performance measures in the manufacturing industry in Kenya also ought to be done.

\section{References}

[1] Awad, A.H. and Nassar, M.O. (2010) Supply Chain Integration: Definition and Challenges. Proceedings of the International Multi-Conference of Engineers and Computer Scientists (IMECs 2010), 2010, Vol. 1, Hong Kong.

[2] Grant, R.M. (1991) The Resource-Based Theory of Competitive Advantage: Implications for Strategy Formulation. In: Zack, M., Ed., Knowledge and Strategy, 3-23.

[3] Foran, B., Lenzen, M., Dey, C. and Bilek, M. (2005) Integrating Sustainable Chain Management with Triple Bottom Line Accounting. Ecological Economics, 52, 143-157. https://doi.org/10.1016/j.ecolecon.2004.06.024

[4] Windsor, D. (2002) Stakeholder Responsibilities: Lessons for Managers. Journal of Corporate Citizenship, 6, 19-35. https://doi.org/10.9774/GLEAF.4700.2002.su.00005 
[5] Elkington, J. (1994) Towards the Suitable Corporation: Win-Win-Win Business Strategies for Sustainable Development. California Management Review, 36, 90-100. https://doi.org/10.2307/41165746

[6] Safaricom Sustainability Report (2014) Sustainability Strategy. http://www.safaricom.co.ke/sustainabilityreport/basic-report/strategy.html

[7] Parmigiani, A., Klassen, R. and Russo, M. (2011) Efficiency Meets Accountability: Performance Implications of Supply Chain Configuration, Control, and Capabilities. Journal of Operations Management, 29, 212-223. https://doi.org/10.1016/j.jom.2011.01.001

[8] Gopalakrishnan, K., Yusuf, Y.Y., Musa, A., Abubakar, T. and Ambursa, H.M. (2012) Sustainable Supply Chain Management: A Case Study of British Aerospace (BAe) Systems. International Journal of Production Economics, 140, 193-203. https://doi.org/10.1016/j.ijpe.2012.01.003

[9] New, R. (2004) Westbrook (Eds.), Understanding Supply Chains: Concepts, Critiques, and Futures, Oxford University Press, Oxford, UK, 253-280.

[10] Salancik, G.R. and Pfeffer, J. (1978) A Social Information Processing Approach to Job Attitudes and Task Design. Administrative Science Quarterly, 23, 224-253. https://doi.org/10.2307/2392563

[11] Benton, W.C. and Maloni, M. (2005) The Influence of Power Driven Buyer/Seller Relationships on Supply Chain Satisfaction. Journal of Operations Management, 23, 1-22. https://doi.org/10.1016/j.jom.2004.09.002

[12] Mitchell, K., Agle, R. and Wood, D. (1997) Towards a Theory of Stakeholder Identification and Salience: Defining the Principle of Who and What Really Counts. Academy of Management Review, 22, 853-886.

[13] Hart, O. (1995) Corporate Governance: Some Theory and Implications. The Economic Journal, 105, 678-689. https://doi.org/10.2307/2235027

[14] Halldórsson, Á., Kotzab, H. and Skjøtt-Larsen, T. (2009) Supply Chain Management on the Crossroad to Sustainability: A Blessing or a Curse? Logistics Research, 1, 83-94. https://doi.org/10.1007/s12159-009-0012-y

[15] Holliday, C.O., Schmidheiny, S. and Watts, P. (2002) Walking the Talk. The Business Case for Sustainable Development. Sheffield (UK)/San Francisco (USA).

[16] Yin, R.K. (2003) Case Study Research: Design and Methods. 3rd Edition, Sage, Thousand Oaks, CA.

[17] Ellram, L. (1996) The Use of the Case Study Method in Logistics Research. Journal of Business Logistics, 17, 93-138.

[18] Seuring, S. and Müller, M. (2008) From a Literature Review to a Conceptual Framework for Sustainable Supply Chain Management. Journal of Cleaner Production, 16, 1699-1710. https://doi.org/10.1016/j.jclepro.2008.04.020

[19] Miles, M.B., Huberman, A.M. and Saldana, J. (2014) Qualitative Data Analysis: An Expanded Source Book. 3rd Edition, Sage, Thousand Oaks, CA.

[20] Eisenhardt, K.M. (1989) Agency Theory: An Assessment and Review. Academy of Management Review, 14, 57-74.

[21] Isaksson, R., Johansson, P. and Fischer, K. (2010) Detecting Supply Chain Innovation Potential for Sustainable Development. Journal of Business Ethics, 97, 425-442. https://doi.org/10.1007/s10551-010-0516-Z

[22] Strauss, A.L. and Corbin, J. (1998) Basics of Qualitative Research: Techniques and Procedures for Developing Grounded Theory. 2nd Edition, Sage, Thousand Oaks, CA. 
[23] Pagell, M. and Wu, Z. (2010) Balancing Priorities: Decision-Making in Sustainable Supply Chain Management. Journal of Operations Management, 29, 577-590.

[24] Bryman, A. and Bell, E. (2007) Business Research Methods. Revised Edition, Oxford University Press, Oxford.

[25] Miles, M.B. and Huberman, A.M. (1994) Qualitative Data Analysis: An Expanded Source Book. 2nd Edition, Sage, Thousand Oaks, CA.

[26] Riege, A.M. (2003) Validity and Reliability Tests in Case Study Research: A Literature Review with "Hands-On" Applications for Each Research Phase. Qualitative Market Research: An International Journal, 6, 75-86. https://doi.org/10.1108/13522750310470055

[27] Freeman, R.E. (1984) Strategic Management: A Stakeholder Approach. Pitman Publishing Inc., Marshfield, MA.

[28] Carter, C.R. and Rogers, D.S. (2008) A Framework of Sustainable Supply Chain Management: Moving toward New Theory. International Journal of Physical Distribution \& Logistics Management, 38, 360-387.

https://doi.org/10.1108/09600030810882816 